\title{
Strength v cleanliness: how images of masculinity and equality shape women's industrial position in a "man's world"
}

\author{
Cathy Wylie*
}

In this article, emphasis is given to the cultural or symbolic dimension of work organization and industrial relations style in order to find a fuller explanation for the low participation of women in trade unions. To show the significance and operation of this dimension, the article concentrates on the description and analysis of an illuminating situation, the Gear freezing works in 1975.

During International Women's Year, 1975, there was much talk in New Zealand about "the changing position of women", and the path to ever fuller and varied participation in the workplace seemed bright (Labour and employment gazette, 1975; United Women's Convention, 1975). A case of knock - have the confidence to knock - and the door shall be opened. Yet while it was no longer respectable to refer to women, publically, as sconemakers nonetheless there was an emotional intensity to the discussion of "Women's Lib", as feminism was known, which indicated that although there was a limit to the "logical" barriers which could be raised, the rethinking of what women did in terms of equality struck a raw nerve for many New Zealanders.

Anthropologists, disposed to think of societies in terms of patterns of behaviour, thinking and relating which interweave to make a dynamic whole, sometimes refer to such raw nerves as "total social facts" (Mauss, 1970). What they mean by this is that a series of social relationships are compressed together in an event such as a ritual, or a more mundane way of arranging say the layout of a house, the gathering of a harvest so that the event or arrangement is an intense expression of much that is significant to a group of people. Such occurrences reveal the relationships which are so fundamental to them that to question or break the associations is to question the familiarities which, for them, make the world real in a particular way. The depth of such situations makes them especially illuminating of the overall social world. For anthropologists, such "symbolic" matters are telling; the ways people talk about what goes on around them reveal the patterns of what they see - what they can see. This goes beyond simply ascribing what people say to interest or bias. The patterns or chains of associations which structure our awareness are not readily conscious, because they are embedded in our everyday activities and relationships; they seem "natural", "the way things are".

So it seemed to me, as an anthropologist, that perhaps the reason for the emotional heat with which calls to alter the nature of domestic and work organization were met, were, in part, to be found in the symbolic associations which people were making unconsciously, and that these pointed in turn to the touchstones of New Zealand reality.

* Anthropology Department, Victoria University of Wellington.

In translating anthropological material and framework to an industrial relations perspective, I owe much to the editor's comments and encouragement, and the anonymous referees' critiques of the first draft of this article. 


\section{Cathy Wylie}

To find out what these associations were, and how they related to the specific work and domestic experiences of people, I spent most of 1975 informally interviewing, but in some depth, a range of people spanning the social spectrum. I also spent brief periods, each of 3 weeks, in 4 contrasting workplaces: a cigarette factory, an insurance office, an advisory section of a Government department, and a freezing works. In each place, I worked alongside people where I was able, talking to them about what they did, what they thought about their work and family life, with the emphasis on relationships between women and men; and observing the interaction and conversation of the people around me, trying to see how it all fitted together. The theoretical perspective used in this article can be called "interpretive" though it belongs to no school (Sennett and Cobb, 1972; Lewis, 1978; Raibnow and Sullivan, 1979; Sartre, 1963).

The material from the freezing works, the now extinct Gear Meat Works at Petone, is particularly revealing of the spiralling connection between what people do in their daily lives, how that is organized, and the symbolic associations and images which they draw from their experience to then use as confirmation, or a basis for action which further confirms their view of things. Amongst other things, the material, analysed in terms of symbolic associations, how people create their own reality, albeit unintentionally, and often in contradiction to stated ideals, sheds some light on the reasons for women's uneasy participation in trade unions. Geare et al. (1979) and Pollert (1981) have canvassed some of the major factors put forward by analysts of the workplace. The former point out that apathy regarding union participation is not restricted to women, and that there is a considerable overlap in reasons, e.g. that union activities should be in the hands of the most experienced. Nonetheless, women are proportionately less represented in union activities. Geare et al. sum up many of the reasons for the difference as "job-oriented barriers" (p.38). This includes such things as the more limited work available to women and the disruption of working experience and careers through childrearing. They also note lack of encouragement in the attitudes of union office-holders toward women, based in part upon the third prime cluster of reasons they identify, the anchorage of women's identity in family and home. Pollert gives more weight to the attitudes of co-workers and union officials, since in her study of a tobacco factory in England many of the men thought their fellow workers who were women had a different reason for working than themselves, were less interested in wage matters because they were less dependent on the moneys they earnt. She also emphasizes constraints on time and attention due to family and domestic responsibilities which do not exist to the same extent for men.

The Geare et al. study is based upon questionnaires addressed to rank and file unionists, and a survey of women union leaders. The unionists belonged to "those with a reasonable number of female members. The term 'reasonable' was defined as not less than 30 percent of membership to be females as long as the female total exceeded 100" (p.24). Pollert's study is based on participant - observation of a cigarette factory where the majority of workers were women. What is interesting about the freezing works material reported here is that women had only recently entered its workforce (1975 was the seventh season of their employment on the processing floor); their numbers had increased rapidly in that period from a handful to 96 at the season's height, 12 percent of the total floor workforce; and their union participation seemed to be declining rather than growing. When women were a novelty, and both union and management conscious of a different group presence in the works, there had been a couple of women delegates from departments with heavy female employment. But for several seasons prior to 1975, and in 1975 itself, there were no women delegates. Unlike most of the unions surveyed by Geare et al. or the tobacco section of TGWU to which the women Pollert studied belonged, the union at Gear was an integral part of everyday work. Delegates were active in stemming grievances; meetings were held regularly during working hours, with the shed as a whole meeting once a month, with the first hour paid. So the union at Gear was not a foreign body at the other end of a receipt book or telephone. Nonetheless, the women were not represented as their numbers would suggest in the union hierarchy, and they were nervous about speaking in meetings. They frequently said that though there were points they would like to make, things they 
would like to speak about, they felt intimidated by the reactions they received from the men.

What I want to look at in more detail in this article is the nature of that reaction, and the organizational and cultural reasons for it. So far this underlying dimension has not received the attention it deserves in industrial relations writing. ${ }^{1}$ But I believe that the close examination of everyday or mundane behaviour, and comments in the workplace has much to teach us about the reasons for discrepancies or inconsistencies between the ideal system of industrial relations, as it appears on paper, and the actual nature and effect of events marking the life of such systems. I include in this article both a general overview of the situation at Gear in 1975, and an anthropological description of an event, the handling of a complaint from one of the women working in the fancy meats department.

\section{Women in a "man's world"}

The freezing works in New Zealand have long occupied a key position in the country's economy. Symbolically, they have also been important. Here the rural combines with the industrial domain, in contrast to their often competitive relations. The nature of the work and its setting - arduous labour, skill with a knife, the smell and sight of blood - have also made the freezing works a potent symbol of masculinity. ${ }^{2}$ The ability to earn comparatively "good money" (compared with other factory or labouring work) through physical effort, and the availability of work on a seasonal or temporary basis has also allowed the freezing works to be a fairly mixed workplace. The permanent employees have found themselves joined by middle-class students, white-collar workers seeking a change, and often found themselves more able or at least on par with men whose work is of higher status. Long-term employees at Gear often told me with pride of how people they had worked with had gone on to train as accountants, doctors, lawyers and the like. They saw the freezing works, and by extension themselves, as helping people to advance, and through that help, stating a basic equality with people in more prestigious and powerful positions. It works the other way also; for many professional men, their season as a student in the freezing works (or the wool store or on a building site) is a symbol of their ability to mix with different people, and proof of their ability to tackle "tough" work, to be accepted by men working in a "man's world". 3

But the aspects which made freezing works such as Gear a man's world have been much altered over the last 15 years. The production process has become increasingly mechanised and specialised. Hot water, hairnets and stainless steel symbolize the continuing quest to satisfy ever changing hygiene regulations imposed by export customers, in an increasingly competitive market. Although the boners and butchers are still the most highly paid, skill with a knife, combined with stamina and muscular strength, are no longer so important.

And women have come into the works. At first there was the stray biochemist collecting samples, as the hygiene regulations narrowed. Then women were hired to pack meat, as overseas customers were found to be impressed with precut and packaged meat rather than the traditional carcase in stockingette. They impressed the management as reliable, clean, and conscientous workers, and other areas opened to them. So the entry of women into the works is associated with the growing emphasis on cleanliness, "hygiene", which has occurred at the loss of the "masculine" atmosphere.

The 1975 season is interesting because it was at an interim stage where this process was still coloured with memories of the tougher but "good old days"; when women were no longer a novelty, but were still noticeable, still symbolic of the changes.

1. Some notable exceptions are : Beynon (1973), Cavendish (1982), Herzog (1980) and Pollert (1981).

2. Eg. Greg McGee's (1984) play Out in the cold.

3. As an example, Ross Martin - a New Zealand-trained industrial relations scholar -, in a very brief autobiography ( 65 words) lists that "before embarking on an academic career", he had "worked in various jobs" including "meat worker" (Martin, 1975, p.i). 
During this season at Gear, 96 women were employed, excluding office staff. Quite a number of these worked in the boning room, packing and trimming meat. The lambpack department, one of the smallest, was almost totally female - apart from its foreman. Women were also a sizeable presence in fancy meats (trimming and packing offal); on the cooling floor of the mutton board, and as labourers on the mutton chains. Some of the quality controllers were women, though none of the Government employed meat inspectors. Women were not to be found in the beef room, the freezers, rendering, fellmongery, or the stockyards. There were no women foremen, chargehands or floorwalkers. There were no women butchers or boners. So the women had come into the works, but there were definite limits to their participation. Why?

\section{Symbols of masculinity}

Most of the men I spoke with could not see a woman employed as a boner, or as a freezer hand because such jobs required physical strength which they did not think women had. Time and again, men spoke of the limits to women's employment in the works in the image of "lifting". Equal pay for equal work was all very well, but when it came to lifting a carcase, women would look to men for help. There was in fact only one section where women were currently employed where this could be put to the test, the cooling floor of the mutton board. Elsewhere the work of the women - and the men alongside them, did not involve lifting of a continual or heavy nature, even though "lifting", and the implication of physical strength, is one of the common images or symbols used to maintain the character of the freezing works, and thus the ability of those who work there, as tough and rigorous. The women working on the cooling floor in fact did pick up carcases which fell from the chain; they also noted that often "the young guys rush over and heave it up before you've got a chance to do it yourself". These same younger men assured me that women needed help, confirming their belief, making it real, by continually helping, unasked. In such incidents, the divide between male and female workers is maintained, and the superior strength of the men - the very framework in which "strength" becomes a major criterion of value - underlined.

The toughness of the freezing works - or the image of toughness, appropriated from prominent jobs such as boning or the lifting in the freezers - arises partly from the emphasis on the (ever decreasing) physical nature of the work. But it also stems from the style in which people talk, the style in which they behave. So, even men who did feel women had the ability to bone or lift, said that they would not like to see their wives in the company.

Matt, the boning foreman (the names have been changed in this article), was one of these. He noted that it was "a young man's job"; and even then not all the men who would like the prestige and higher pay of boning are capable. From this, he drew the conclusion that while certainly not every women, as not every man, could do the job, there would be some who could. Indeed, the first woman boner in New Zealand was employed in the following season by another North Island freezing works. She has since been joined by a small number of other women, including the 4 who had to resort to the Human Rights Commission to win their case for training as boners at Ocean Beach.

Swearing is a prominent aspect of this expression of toughness in language. It was a prevalent aspect of ordinary conversation, jokes, and confrontations. The words used, the innuendo jokes traded back and forth, in fact perturbed only a small number of the women. Though it was more frequent, it was not worse than they had heard or used in other workplaces, particularly other factories. Yet it was the men's common belief that their language was "worse" than other workplaces, and much worse than women's. In part, this is because few of them had worked with women before. Quite a number also, especially the older men, had wives who did not work outside the home, and who associated women with the home, and a different style of language and behaviour than that they knew from work. But since the expression of "toughness" has become narrower, 
with cleaner and more mechanized jobs and surroundings, swearing has become more important symbollically as a statement of toughness, of masculinity.

The men's understanding placed the women at the works in an awkward situation. If they swore to the same extent, especially in confrontations, or public arenas such as the union shed meetings, they were regarded with suspicion. They must be "unwomanly" or "coarse" to behave so.

If, however, they did not behave as the men, and most did not, they met with a different suspicion. This comes out clearly in the comments of the president of the local branch of the freezing workers' union when my entry as a researcher into the works was being negotiated with management. "Yes", he said, "I support equal pay for women, so long as they can do the same work as a man". The Works Manager then commented "Some of the women work a great deal harder than some of the men about the place". The union president replied, "I can't deny that. The trouble is, I can't take them outside like I can a man. I've been brought up to think you shouldn't hit a lady back though no doubt there's plenty in there that would land me a punch. I'm not very popular with the women, but they still smile and say 'Hullo Mr Bates'. The men who don't like me wouldn't".

The style of settling differences between workers, or between management and workers, and expressing different interests and feelings is also one of "toughness". Sometimes it took the form of tests of strength, whether verbal or physical, or simply a refusal to back down. Matt and the other boning room foremen in fact commented that the level of "scraps" had diminished considerably since women joined their department. They spoke of a "more pleasant" working atmosphere.

Yet at the same time as Matt and the others enjoyed the women's presence, they were puzzled in the same way as the more wary union president (who worked in the freezers). The women did not express dissatisfaction, or voice complaints in the same way as the men, in the style they were familiar with. Matt summed it up as a "Yes Boss" attitude. They did the work all right, and were far more reliable than many of the men, and more willing to do work regarded as boring. But that very willingness, and their silence, where men would be openly grumpy, or slaphappy when the boredom hit saturation level, made him uneasy. He felt that the women were storing up their grievances, to talk amongst themselves.

Where Matt's solution was to wonder whether it would help to have a woman foreman, other men read the difference as a difference in essential character between the sexes. If woman did not talk back to them in the way in which they were accustomed, the "natural" way, it was because women were underhand. It also seemed to them, as it did to the union president, that women were somehow unfair, receiving equal pay, yet needing a different treatment. "You're not able to bawl them out in the same way. If a guy goes out for five minutes without permission, I yell at him; but if a woman disappears to the toilet, I can't say much to her. It could be some female complaint". Like the rushing to lift a carcase for a woman, this view, implied in the mysterious image of "female complaint", invisible aches and pains, maintains and makes real a general distinction between men and women in terms of physical things, the body, an irreducible fact of nature. It hides the way people's behaviour, and valuation of each other, shapes and constrains our understanding of things, and here, makes the difference between men and women a fact of nature, something fixed, and not a result of cultural practice, open to alteration.

In the way that the men, noticeably so with the men in charge, read the difference in response to working conditions and job allocation as a deviation from the norm, the way the women behave is negatively valued. It is not simply different. By being different, it is unfair because it seems to need a different treatment. And that means that things are not equal, because they are not identical, are not "the same". So one of the major stumbling blocks to women's wider participation in the freezing works is their challenge to the notion of equality as sameness.

The other major hurdle, or hidden barrier, is that the prevailing style or ethos is couched 
in "toughness" - and this is not how women should behave. (If they do, then the difference between men and women cannot be seen any longer as one of superior strength). Yet if they act differently, they are met with suspicion, or lose credibility. One of the strongest examples of this is in the voicing of a complaint. Complaints were usually made immediately and directly. Often women hesitated, deciding whether or not they had a fair case; possibly also, because many of them were unused to a constant availability of union staff. If they did hesitate, they were seen as "brooding". Because they felt unsure of their standing in the works, it often did take some time for them to come forward with a complaint or request. The foreman and union delegates, equating importance with immediacy, and sometimes seeing an alteration to a decision as a "backing down", an expression of weakness, thus came to the conclusion that their complaints were "petty", or "underhand".

\section{Symbols at work : The fancy meats complaint}

The interaction of these perceptions of difference in terms of masculinity and equality can be seen clearly in the manner of a complaint from one of the women working in fancy meats, and the responses it occasioned by management, union officials and fellow workers, women and men.

The fancy meats department trimmed and packed offal from both the mutton chains and the beef room. The women worked in the centre of the department, just under the window of the foreman's office, packing hearts, brains, kidneys etc. from the mutton board on the floor above. The work was static and monotonous, though the noise level was low enough for some conversation to be maintained. Work with offal from the beef room was done by men. The material they worked with was larger, heavier, bloodier; men's stuff. Because some loading from the freezers was involved, the pay rate was slightly higher. And since women had begun working on the "belt" 4 seasons ago, the men had become increasingly reluctant to work there, saying it was "women's work". Women had broadened their presence, moving into a range of departments, but within departments, their jobs were usually the more static and monotonous, requiring patience. Patience and remaining in place are not associated with being masculine, or being tough, the prevailing value of the freezing works. The jobs women were doing were seen as easy and boring; they became even more boring and unmasculine because the women did them. Yet the women could also be seen by the younger men, and some of the employees who had worked there for a long time, gradually pulling back to jobs such as packing, as a threat, and receiving unequal treatment because the jobs were thought of as "easy". Resilience in the face of boredom was not perceived as strength, but instead the lack of initiative.

Although there were 44 employees in the fancy meats department, 36 men and 8 women, the proportions were more even at the end of the season after layoffs, because the women had longer service, and so were higher on the seniority list. The foreman had not wanted women in his department; the union delegate and his deputy, who both worked in the beef section, were also uneasy with the presence of women as co-workers. Both men expressed the belief that as union delegates they had to "let them (fellow workers) know what's what", and "get tough". Several times during my week in the department they were called to resolve, or intervene, in scuffles and arguments over job boundaries and turns for smoking breaks. The men involved voiced their disgruntlements and disputes publically, quickly, and in "tough" language. None of these disputes involved women.

The women, however, were caught up in dissatisfaction over the foreman's ending of the rotation of jobs on the belt, which some of the women had asked for, following practice in the beef section, to ease the monotony. He had agreed reluctantly. They rotated work for a couple of weeks, when he decided to return to the original scheme. When one of the women complained, he sent her to work in the beef section as a form of punishment. This was his parallel to the discipline given men who are felt to be making nuisances of 
themselves; they were given work in the tripe room, work which is messy, smelly, monotonous and lonely.

The woman involved did not make an immediate fuss. She talked with other women on the belt. The talking further divided the women. Some of them had not wanted the rotation, and were felt by the complainant and those who had wanted it to have been the main force behind the foreman's decision because they were "chummy" with him. The husband of one, another foreman in a different department, was also a regular at the card games held during breaks in the foreman's office (as were the union delegates). To those who had sought the rotation, its ending seemed due to personal favouritism. The foreman did not clarify his reasons for ending the rotation; and the women did not go to the union delegate, as the men in the department would have done in similar circumstances - even had they felt, as the complainant did, that he was too close to the boss to put her case.

When she did approach the delegate, her doubt made her awkward in expressing her case. The union delegate's reaction was suspicious, irritated, and couched in the masculine "tough" style. Because the women do not use this style themselves, they find it intimidating and unhelpful.

The union delegate told her, and others listening, that the boss had not gone back on his word. They had stopped rotating because they were not operating a full complement. In any case, she could not pick where she was going to work. "If it was up to me", he went on, "I tell you, I'd put you in the tripe room. You should be there anyway, you're getting equal pay, you should take your luck like the men". One of the other women noted that the boss would not let them work down there. The delegate said, "That's a pity. He's too easy a boss - you don't know how lucky you are".

The complainant finally won the delegate's willingness to act when she said that the foreman had threatened to sack her for complaining. However, he also asked her roughly why she had not done anything about this before (it was 3 to 4 weeks later). He concluded the discussion by saying that the problem was caused by the women themselves. They were the ones who should solve it (although he had earlier said that the decision over rotation was not the employees' to make) and that the women were just bitching and backbiting. The women who were there nodded their heads in agreement.

However, the complainant finished by saying she would take the case higher up, if it could not be solved at this level. It remained unsolved. Two days later, at the monthly shed meeting, she presented her case - again with embarrassment and uncertainty rather than with the confidence of someone doing what is normal or an unequivocal right in the circumstances. There was no response from the floor after she had finished, as if the matter was rather trivial. The fancy meats delegate then gave his impression of the situation in the department, at the behest of the union secretary. The union secretary, who is seen as sympathetic to women, ${ }^{4}$ did not immediately respond to the original grievance, but he did to the threat of sacking. "No one is going to get away with intimidation threats to a member of the union". He came down to the fancy meats department after the shed meeting, and took the complainant and the delegate in with him to see the foreman.

4. The union secretary was the prime mover of changes to seniority listings which based position solely on time served. Before then, married women had been amongst the first to be laid off, despite length of employment. It is worth noting that the seniority lists were still sources of grumbling with regard to the women. Some of the men still felt that married women should go first - they couched their feelings in the belief that it was the husband who was the breadwinner; and some of the older men also talked about the "greed" which sent married women out to work, since they felt that the earnings of the breadwinner should be sufficient. Some men and some women felt that married men with families should be given priority over women - though a reasonable proportion of the women working were single parents. No one thought of single men as candidates to go first, even though responsibilities for dependents was one of the considerations voiced. (In general, the women were mostly married or divorced). The company did not, officially, employ women under 24 , apart from a teenage clerk on the weighbox of the mutton board. The minimum employment age for men was 15 . The company nurse told me that the company wanted to employ "mature" women; they were asked about their childcare arrangments when they began work, as with their plans for future children. 


\section{Cathy Wylie}

They arranged a general meeting of the department for the next day, to settle the matter.

Amongst the men, opinion was not uniform on the rightness of the complaint. The sympathetic focused on the representation of her case by the union delegate, repeating that he and the boss were too close for it to be a fair representation. They did not comment on the details of the complaint. Others wondered why she had taken "so long" to make her complaint: to them this drew the credibility of her case into question. The most unsympathetic viewed it as an example of the kind of trouble women made by "the way they carry on". There was talk that the foreman would solve matters by not employing women in the next season.

So the complaint was not seen in the same light as a similar case involving a male complainant; it became an illustration of the shortcomings of women as a general type.

The women too perceived the case more in terms of supposed attributes of women. The divide between them was seen as evidence of "bitchiness", "gossip", and not as the clash of different interests within a shared work process, which was decided by a boss who did not communicate equally well with women, as with the men in his department, or communicate equally with all the women. The static working position of the women, confined to the belt dealing with sheepmeat, also contributed to the division. Disputes between men were sometimes resolved by both management and union delegates through the simple physical separation of the men involved, allocating them jobs which took them away from each other. Other organizational factors which gave breathing or cooling off space to the men's disputes, and disputes were not uncommon, were the rotation of their work, and a more general mobility 5 in the kind of work they did, e.g. bringing things from the freezer and filling trays rather then remaining at the belt all the time. There are structural factors at work in the way conflicts arose and were solved which differed for men and women. Yet these structural factors are read by most of those employed in the freezing works as attributes of gender, evidence of male or female character.

When the union secretary and president showed up for the department meeting the next day, the outcome was that the secretary would carry out further investigations as to what exactly had happened. The investigations were to centre on whether the foreman had actually threatened to send the complainant "down the road" because she had complained about the change. The union officials did not feel she had a justified grievance in being told by the foreman that he would "send her down to the tripe if she didn't behave", though they did suggest that the manning situation in the department deserved attention.

What is interesting in this case is the way the union officials couched their reasons. They noted the general principle that the foreman had the right to place his labour where he wished. But they went on to say that the women were on equal pay, and they should feel lucky that the boss did not put them in the tripe room. Again, "equal" is taken to mean, "same"; even though the foreman had in fact defined some of the work in the department as unsuitable for women. This definition became a count against the women, as if it were a privilege or choice they themselves have asked for or taken. And "equal pay for equal work" became used to refer to the difference between the jobs women were allowed to take on, and the breadth and variety (and on the whole better paid) work available to the men - and not the use of one pay scale for all workers doing the same job. Such usage confused the women in their perception of their actual situation. They did receive the same rate of pay as men who did the same work, they were told they were getting equal pay - and yet they did not seem to stand on the same or equal ground as
the men.

5. Most of the men had been around the works, and had some idea of the different processes involved. It was not so easy for the women to move around - they were highly visible in the all-male departcan be given in the interest with comparative immobility with regard to the workplace as a whole board accompanied me to the top of the woman assigned to keep an eye on me on the mutton first time she had been up to the beginning of the line. 


\section{"We don't speak up enough for outselves"}

Though none of the women I spoke with in the freezing works would have any truck with "Women's Lib", the continual emphasis and valuation of their gender by both management and union had led at a general level to their perception of women as a group with particular interests in the workplace. Yet the description of these interests varied from wanting lockers by departments, as the men did, to wider work opportunities, or the rotation, similar to the men's, sought by some of the women in fancy meats. The women did not act as a group or organized lobby, however. In part this is because there were different interests amongst them; in part because of the organization of the works and union by departments, so that women were on different seniority lists, different pay, with different delegates and foremen whose sympathies toward the newcomers to the works varied.

But the emphasis on the "tough" style in public settings also inhibited them. Several women who had spoken up at the shed or department meetings including the former delegate from lambpack, who said "We don't speak up enough for ourselves", spoke of being "houhahed", yelled down because, they felt, of their sex, rather then the worth of their viewpoint. They had been told that it was "a man's world", and if they wanted to work there, all very well, but they should accept things as they found them. In other words, gender was used as the litmus test of views and ideas.

One illustration of the part played by the perception of women as different from men - having different interests, a different style of doing things which somehow competed with the men's, or was not compatible with it, is the decision of a women on the mutton board not to go forward as union delegate, though she had been asked to by the other labourers on her part of the chain. She had a reputation for being coarse and rough because she did in fact "give as good as I get", and employ the masculine style of toughness. But she thought again when the section foreman, with whom she had a good, bantering relationship, told her not to accept, because "I can't argue with a woman". In a wry irony, this woman, thought of as rough, was flattered by being seen as different from the men around her, and thus dissuaded from becoming a union delegate.

\section{Difference and equality}

The differences made between women and men through the jobs they do within the same workplace, the style of talk and behaviour are important because they make a further difference: they underline the different valuation of men and women, and the continuing use of gender as a category with significance. Women may have moved into the man's world of freezing works - as it becomes cleaner, more mechanized, less "manly"6 but they are not at home there. They symbolize what are to many male employees regrettable changes: the increasing routinization of their work, the changing status of unskilled work.

And for many men there, as with the women, their prime image of the relationship between women and men stems from marriage. Almost without exception, the freezing workers' experience of marriage, and their expectations of it, were based upon a division of work and responsibilities which provided a complementarity from one angle, but which also emphasized the sexes as different from another. A woman as wife and mother's domain was the children and house, and, by extension, domestic interests. A man as husband and father was the breadwinner, the income provider. Because money is a prime

6. In the company handbook given to new employees, there is a telling plea for respect for the hostel manager: the domestic work is emphasized as demanding - as "man-sized":

Men in the hostel will meet the hostel manager when they arrive. He is responsible for the allocation of rooms, issuing of blankets etc. To keep order with such a large number of men in residence is a man-sized job and this is where you can help...

The hostel was available to men only. 
indicator of worth in New Zealand, as well as a necessity, by extension the husband was, or should be, the dominant figure in the relationship. Men expressed their belief that though men and women were equal, they themselves were still "head of the house". Women said that the sexes were equal all right - but they would like "a shoulder to lean on".

When I asked whether people could see a woman becoming Prime Minister, very few could imagine a woman as head of the country, as only one or two could see the possibility of a woman foreman, that is, someone different, thus somehow unequal giving leadership, and orders, to men. The almost unanimous opinion in the freezing works is quite marked by contrast to the more mixed reception this question got in other workplaces - perhaps because few there had had experience of women in charge, as well as the strong masculine emphasis to the work.

There is a qualitative difference between the image of equality drawn from marriage from complementary relationships; and that image of equality, drawn from men using the same physical resources side by side, sharing the same experience; being "strong" in the same way. Though people are using the same word - "equality" - they are in fact referring to different valuations of people vis a vis each other, valuations all the more concealed because they are drawn from experience, albeit also playing a large part in the shaping of that experience.

The freezing works bring out this often confusing and pacifying ambiguity very clearly, because the imagery of the difference between men and women, and the imagery of masculinity and equality are overt. The work organisation, content, and union presence are very different in other workplaces, e.g. the retail trade, restaurants and offices where many women work. Nonetheless, the kinds of unconscious associations discussed in this article are also at work in those situations; the evaluation of women's work and working which constrains women's fuller participation in both the workplace and industrial relations matters. It is crucial, if this participation is to be achieved, that the structural, organizational and cultural factors be recognized and analysed; and the framework of valuation by gender and style be seen as a cultural construct, something which does not explain (e.g. "women are more patient than men"), but which itself needs to be explained by placing it within the wider and more subtle context of the interrelation between people's mundane experiences and the confirming and consolidating images they draw from them.

\section{References}

Beynon H (1973) Working for Ford Harmondsworth, Penguin.

Cavendish R (1982) Women on the line London, Routledge \& Kegan Paul.

Geare A J, Herd J J and Howells J M (1979) Women in trade unions : a case study of participation in New Zealand Wellington, Industrial Relations Centre, Victoria University of Wellington (Industrial Relations Research Monograph No. 6).

Herzog M (1980) From hand to mouth : women and piecework Harmondsworth, Penguin.

Department of Labour (1975) Female participation in the labour force in recent years Labour and employment gazette, 25(1):9-12.

Department of Labour (1975) Women in unusual occupations Labour and employment gazette 25(2): 13-16 and 25(3):31-34.

Lewis M (1979) The culture of inequality New York, New American Library.

Martin R M (1975) Trade unions in Australia Harmondsworth, Penguin.

Mauss M (1970) The gift London, Routledge and Kegan Paul.

McGee G (1984) Out in the cold Wellington, Victoria University Press.

Pollert A (1981) Girls, wives and factory lives London, Macmillan. 
Rabinow P and Sullivan W M (1979) Interpretive social science Berkeley, University of California Press.

Sartre J-P (1963) Search for a method New York, Alfred Knopf.

Sennett R and Cobb J (1972) The hidden injuries of class New York, Alfred Knopf. United Womens Convention (1976) Report Wellington, U W C. 


\title{
RELATIONS INDUSTRIELLES INDUSTRIAL RELATIONS
}

\author{
SOMMAIRE - CONTENTS
}

volume 39, numéro 1, 1984

La détermination des avantages sociaux au Canada Jean-Michel COUSINEAU et Robert LACROIX

Determining Fringe Benefits in Canada

The Negotiation of First Agreements in Ontario: An Empirical Study Norman A. SOLOMON

La négociation de premières conventions collectives en Ontario

Le travail des deux conjoints: effet sur la progression de carriere du cadre Jean-Yves LE LOUARN, Roland THERIAULT et Jean-Marie TOULOUSE

Working Spouses' Impact on Managers' Career Progression

L'information des travailleurs dans les grandes firmes:

l'approche spécifique de la CEE

F. VANDAMME

Information for Workers in Large Companies: The EEC Approach

The Determinants of Strike Activity: An Interindustry Analysis

Dennis MAKI and Kenneth STRAND

Les caractéristiques de la grève selon les branches industrielles

Community Influences on Attitudes Towards Unions

Harvey KRAHN and Graham S. LOWE

L'influence de la collectivité locale sur les attitudes envers les syndicats

L'approche systémique en relations industrielles

Viateur LAROUCHE et Esther DEOM

The Systems Approach in Industrial Relations

Occupational Segregation and Equal Pay for Work of Equal Value Roberta Edgecome ROBB

La ségrégation professionnelle et le salaire égal pour un travail d'égale valeur

A Real Estate Agency's Analysis of the Climate-Performance Relationship Shimon DOLAN, Aharon TZINER et Denis ROY

Une analyse de la relation climat-rendement au niveau de bureaux de courtage immobilier

Décisions rendues par le Consell canadien des relations du travail LUC BEAULIEU

Changements dans les législations du travail au Canada Michel GAUVIN, Goeffrey BRENNAN et Louis LEMIRE

Recensions - Book Reviews

Publications récentes - Recent Publications

Livres reçus - Books Received

Revue trimestrielle bilingue publiée par le Département des relations industrielles de I'Université Laval, Québec, Canada. - A quarterly bilingual Journal published by the Département des relations industrielles, Université Laval, Québec, Canada. Directeur -Editor: Gérard Dion.

Abonnements annuels - Annual Subcriptions - Institutions: $\$ 40.00$; Individus - Individuals: Canada. $\$ 20.00$ Etranger - Foreign: $\$ 22.00$. Le numéro - Single Issue $\$ 6.00-$ Les Presses de I'Universite Laval, C.P. 2477.00
Quebec, Que. Canada, G1K 7R4. 